\title{
Behind the Facades of Anniversaries
}

Antoshin

Alexey Valerievich Dr. Sci. in History, Associate Professor, Ural Federal University (Yekaterinburg, Russia)
Many professional historians have viewed measures undertaken to celebrate anniversaries of historical events with scepticism. Celebrations connected to memorable dates are often pompous: coffee-table books released for this or that anniversary are frequently official in character, and their scholarly level is not high. Jubilee events often lack an element of discussion, even though, as is well known, the truth is often born out precisely in the clash of opinions.

However, the anniversaries of events often lead to a re-evaluation of their meaning in national history. Jubilees are inextricably connected with the problem of historical memory, one of the most significant topics in the humanities today. As L. P. Repina justly points out, interest in this issue is an important dimension of changes connected with the "anthropological turn" in historical scholarship ${ }^{1}$. The concepts of "cultural memory" and "collective memory" 2 are now actively applied by historians, culturologists, and philosophers across the world. The interrelationship between the concepts of "memory" and "forgetting", which P. Riker ${ }^{3}$ was one of the first to raise, is highly relevant in many countries, including modern Russia.

The Napoleonic Wars and the First World War are inarguably among those events that left a massive footprint in the history of Europe and Russia over the past two centuries. In- 
extricably connected with the "long" nineteenth century, they wield a great influence on the historical memory of many European countries and others across the world. Prepared by a large team of historians headed by Ural Federal University academics Ol'ga Porshneva, Nikolai Baranov, and Vladimir Zemtsov, the work under review is dedicated precisely to analyzing historical memory and the politics of memory in relation to the Napoleonic Wars and the First World War. One of the virtues of the present book is precisely that it presents a "comprehensive view of the problems of commemorating the Napoleonic Wars and the First World War"4.

When characterising this work, it is necessary first of all to remark on the extremely rich source base. Documents from the national archives of Britain and France, the federal and military archives of Germany, the Bundesarchiv, the Bayerisches Hauptstaatsarchiv, the historical service of the French Ministry of Defence, the Russian Archive of Ancient Acts (RGADA), the Russian State Military-Historical Archival (RGVIA), the Russian State Military Archive (RGVA), the Russian State Archive of Socio-Political History (RGASPI), and a range of other repositories allow the authors to provide the reader with unique historical materials. A considerable proportion of the historical sources used in this monograph are entering into scholarly circulation for the first time.

The work is also distinguished by its high theoretical level. Methodological problems of the research are presented in the first chapter. Here, the authors analyze the key theoretical approaches to concepts like "politics of memory", "collective memory", "cultural memory", and so on. The volume demonstrates that these issues are located in a discursive field that has attracted the interest of scholars working in various areas of the humanities. The monograph's authors come to the entirely sound conclusion that it is precisely an interdisciplinary synthesis, drawing on the approaches of historians, philosophers, culturologists, and linguists, that can help us overthrow methodological dichotomies in research into the politics of memory.

The second chapter is dedicated to historiographical aspects of research into the politics of memory and historical memory. Here, a series of analyses is presented on the national historiographical traditions of France, Russia, Britain, and Germany surrounding the study of the Napoleonic Wars and the First World War. Thoroughly characterizing the evolution of scholarship into these themes, the authors come to a range of important conceptual conclusions. For instance, the analysis of the politics of memory in Russia relating to the War of 1812 allows them to conclude that, from the very beginning, the official version of events "merged with popular images of war against an archetypal villain" 5 . Through this, the authors remark that one of the most understudied issues in this area is the use of images of 1812 in patriotic propaganda during the First and Second World Wars, as well as in the organization and holding of jubilee events during the Napoleonic Wars' 150 th anniversary in 1962.

In terms of commemorative practices relating to the First World War, the authors of the reviewed volume identify Russian peculiarities, such as the "glorification of negative historical experience", the underestimation of the "human factor" in war, and the strong influence of "conspiracy theories" on mass consciousness ${ }^{6}$. At the same time, they note that no few difficulties with this matter also exist in Europe, where problems of national identity are being exacerbated in the course of European 
integration. In our view, of particular importance are the authors' conclusions about the negative attitudes of many French people towards how memory of the Great War is maintained by their state, one of the victorious powers: "The politics of memory has been turned into a business facilitated to bring political dividends: historical policies and narratives connected with practices of memory have become a bargaining chip in political debates"7.

In the opinion of this reviewer, one of the most interesting parts of this collective monograph is the third chapter, "Anniversaries of the Napoleonic Wars: Memory and Politics". Many fascinating pages are dedicated to the evolution of the cult of Austerlitz in France and the perception of Trafalgar and Waterloo as "glorious defeats". Particularly intriguing is the characterization of the French perception of the Russian campaign of 1812 as a "victory in defeat". "In the opinion of many French people", they write, "the army of Napoleon unconditionally won the Battle of Borodino and the clash at Berezina, but the overall campaign ended with its complete defeat"8.

The section of the third chapter dedicated to the Russian memory of the War of 1812 is, in this reader's opinion, very strong in conceptual terms. The authors remark that contemporaries laid down two tendencies in the understanding of these events. One "delighted in the defensive, patriotic, and anti-western mood: to a considerable extent, it evolved under the influence of the authorities, although it relied on the feeling of great victory and miraculous salvation that was experienced by different groups in Russian society". The other, presented by the Decembrist generation, "saw in the West not only a threat, but also the source of a freedom-loving spirit, even though this spirit had been to a certain extent enslaved by an ambitious tyrant" . As the monograph shows, the opposition between these two tendencies continued throughout the course of the nineteenth and twentieth centuries, and in many respects has been maintained to the present day. Thus, the pages of this work that critique the preparations and holding of events in Russia for the $200^{\text {th }}$ anniversary of the War of $1812^{10}$ are distinguished by their scholarly courage.

The narrative dedicated to L. N. Tolstoi's novel War and Peace is also interesting. Although it notes that the novel's pages "simply cry out the author's complete disregard for famous moments"11, the book under review recognizes that Tolstoi's piece continues to place a defining weight on Russian society's ideas about the War of 1812. The way in which the authors set up the question about whether "Tolstoi managed to reveal in the collective historical memory of Russians an organic inclination to perceive a variant of the past that only appeared to contradict the one officially prescribed by the authorities, but was in fact sanctioned by them", is highly significant ${ }^{12}$.

The fourth chapter is dedicated to historical memory and the politics of memory surrounding the First World War in the interwar period. Here, the evolution of commemorative practices in the 1920s and 1930s in the USSR, Germany, the UK, and France are characterized. The chapter presents both a detailed description of the institutions that established state control over historical memory in the USSR, and an analysis of changes in commemorative practices in European states. Perhaps most stimulating is the analysis of the "brutalization" of political activities in Weimar 
Germany and the stereotypical and clichéd use of the theme of military experience by the right that ended in the rise of the Nazis to power in 1933.

The book's fifth chapter ("Memory of the Great War When Making Sense of the Experience of the Two World Wars and the Global Transformations of the Second Half of the Twentieth Century") is analogously structured on a country-by-country basis. The chapter's title is no accident: as the authors comment, "the obvious connection of the two world wars created the feeling that those who died in them formed a single community of the fallen"13. The chapter examines the social discussions around commemorative practices connected to the First World War in the victorious powers, Great Britain and France, where it is demonstrated that state structures began to play the largest role by far in the formation of images of the war. Analyzing the situation in the Federal Republic of Germany, the monograph remarks that it is possible to speak of an evolution from a "recognition of the enduring values of the national military tradition to an appreciation for the values of western democracy" ${ }^{14}$.

Conceptually speaking, the section dedicated to the politics of memory around the First World War in the Soviet Union and modern Russia is especially gripping. The authors debate the widespread thesis of the "forgotten" First World War. "If anything was displaced", it is posited, "it was the heroic propaganda image that was formed in 1914-1917 and partially inherited by Russian military emigres" ${ }^{15}$. In reality, the First World War was used in Soviet propaganda, but its "fragmentation, heterogeneity, tangentiality (situativnost') and circumstantiality (kon'iunkturnost') all determined the absence of a single, articulate image of the First World War" ${ }^{16}$. Pointing to the use of images of the war (above all, the Brusilov offensive and the defence of Osowiec fortress) in Soviet propaganda during the Second World War, the authors trace "the displacement to the periphery" of detailed narratives about the conflict in the postwar period.

Undoubtedly, the vast historical canvas that this team have managed to create raises some questions. Above all, the researchers concentrate their attention on historical memory and the politics of memory in a range of key states - Russia/ the USSR, France, Great Britain, and Germany. Of course, historians are conscious of the fact that the First World War in particular left a vast imprint on the historical memory of many other peoples. Unfortunately, only a single sentence is dedicated to this issue, in relation to the British dominions: "The heroism shown by the Canadians by the hills of Vimy and by the Australians and New Zealanders on the Gallipoli peninsula and the sacrifices they bore became decisive factors in lifting the national consciousness of the white residents of the dominions"17. The First World was a key point in the formation of national identity among Australians ${ }^{18}$. The numerous "places of memory" connected with the heroism of the Australian and New Zealand Army Corps (the famous "Anzacs") and the attention paid to the First World War in Australian museum exhibits, historical works, artistic literature, and cinematography all this, in our view, deserves full attention.

It is also necessary to think about a few other narratives that are not reflected in this monograph. In the fifth chapter, for instance, there is an entire section dedicated to Germany that is based on materials from the Federal Republic. But what were the specifics of the politics of memory surrounding the First World War in the German 
Democratic Republic? The GDR's politics in relation to the Second World War are well-known, particularly its lackluster approach to the "overcoming of the past"19. Was the GDR's approach to the First World War similar in this regard?

Unfortunately, the authors also only briefly mention the memory of the First World War in the "second Russia", Russian emigration. This is an indivisible part of Russian history with its own strongly defined characteristics. In conditions where we are talking a great deal about the need to heal the schism between the two Russias, perhaps more attention could have been paid to the activities of the Association of Veterans of the Great War in San Francisco and other similar organisations, which make a vast contribution to maintaining the memory of events from a hundred years $\operatorname{ago}^{20}$.

Unquestionably, however, these wishes are expressed in the form of recommendations rather than criticisms. The present monograph represents a huge amount of historical labour dedicated to an extremely important and relevant theme. Both Russian and non-Russian researchers will doubtlessly find good reason to turn to the pages of these essays in the coming years.

1 Repina L.P. Historical science at the turn of XX-XXI centuries: social theories and historiographic practice (Moscow, 2011), p. 441.

2 See: Assmann J. Cultural Memory: Writing and Memory of the Past and Political Identity in the High Cultures of Antiquity (Moscow, 2004).

3 Ricœur P. Memory, history, Forgetting (Moscow, 2004).

4 Cit. ex.: War, Politics, Memory: The Napoleonic Wars and World War I in the Space of Anniversaries, eds O.S. Porshneva, N. N. Baranov and V. N. Zemtsov (Moscow, 2020), p. 4.

5 Ibid., p. 38.

6 Ibid., p. 69.

7 Cit. ex.: Ibid., p. 84.

8 Cit. ex.: Ibid., p. 130.

9 Cit. ex.: Ibid., p. 189.

10 Ibid., p. 217-222.

11 Cit. ex.: Ibid., p. 196.

12 Cit. ex.: Ibid., p. 200.

13 Cit. ex.: Ibid., p. 415.

14 Cit. ex.: Ibid. p. 478.

15 Cit. ex.: Ibid. p. 489.

16 Cit. ex.: Ibid. p. 490.

17 Cit. ex.: Ibid. p. 357.

18 Blainey G. The story of Australia's people. The rise and rise of a new Australia (Melbourne, 2016), p. 227-237.

19 See: Boroznyak A. I. Cruel Memory. The Nazi Reich as Perceived by Germans in the Second Half of the 20 $0^{\text {th }}$ and Early $21^{\text {st }}$ Centuries (Moscow, 2014).

20 See: Katagoshchina M. V. 'World War I in the Private and Corporate Collections of Russia and the Russian Abroad,' RUDN Journal of Russian History, vol. 18 (1), 2019, p. 151-181. 


\section{FOR CITATION}

Antoshin A. V. 'Behind the Facades of Anniversaries,' Modern History of Russia, vol. 11, no. 3 , 2021, pp. 792-797. https://doi.org/10.21638/11701/spbu24.2021.314

Abstract: The article is devoted to the collective monograph "War, Politics, Memory: The Napoleonic Wars and World War I in the Space of Anniversaries". Prepared by a large team of academics under the leadership of Olga Porshneva, Nikolai Baranov, and Vladimir Zemtsov (professors at Ural Federal University), it is the first generalizing work dedicated to historical memory and the politics of memory surrounding these wars. The monograph uses a large complex of documents from archives in Russia, France, Great Britain and Germany. This book is distinguished by its high theoretical level, which is supported by concepts from leading specialists on historical memory. The authors characterise the specifics of commemorative practices connected with events that were major milestones in the history of the 'long' nineteenth century. The monograph shows the evolution of these practices, which was conditioned by changes in the attitudes of society and the authorities towards the Napoleonic Wars and the First World War. The authors characterise the role of the institutions of civil society in the formation and development of cultural practices connected with the anniversaries of these military conflicts. Most attention is paid to the specifics of commemorative practices related to 'victory memories' and 'defeat memories' in various European countries. This book helps us to understand the contradictory character of state policies towards historical memory, a relevant issue in modern Russia.

Keywords: Napoleonic wars, World War I, historical memory, politics of memory, anniversaries.

Author: Antoshin A. V. - Dr. Sci. in History, Associate Professor, Ural Federal University (Yekaterinburg, Russia); alex_antoshin@mail.ru

Ural Federal University, 19, ul. Mira, Yekaterinburg, 620002, Russia

\section{References:}

Assmann J. Cultural Memory: Writing and Memory of the Past and Political Identity in the High Cultures of Antiquity (Moscow, 2004). (Rus. Ed.)

Blainey G. The story of Australia's people. The rise and rise of a new Australia (Melbourne, 2016).

Boroznyak A. I. Cruel Memory. The Nazi Reich as Perceived by Germans in the Second Half of the $20^{\text {th }}$ and Early $21^{\text {st }}$ Centuries (Moscow, 2014). (In Russian)

Halbwachs M. Social borders of memory (Moscow, 2007). (Rus. Ed.)

Katagoshchina M. V. 'World War I in the Private and Corporate Collections of Russia and the Russian Abroad', RUDN Journal of Russian History, vol. 18 (1), 2019. https://doi.org/10.22363/2312-8674-2019-18-1-151-181 (In Russian)

Repina L.P. Historical science at the turn of XX-XXI centuries: social theories and historiographic practice (Moscow, 2011). (In Russian)

Ricœur P. Memory, history, Forgetting (Moscow, 2004). (Rus. Ed.)

War, Politics, Memory: The Napoleonic Wars and World Warl in the Space of Anniversaries, eds O. S. Porshneva, N. N. Baranov and V. N. Zemtsov (Moscow, 2020). (In Russian)

Received: February 20, 2021

Accepted: May 10, 2021 